\title{
Exploring Multiple Dimensions of Recording Video Clips in Group in Learning English Speaking Skill
}

\author{
Tuyen Nguyen Chau Bich
}

\author{
English lecturer of Faculty of Foreign Languages at Ho Chi Minh City Open University
}

\begin{abstract}
Applying technology in learning English language is indispensable in the period of industry 4.0 and global integration. However, what technological techniques should be applied in teaching and learning process is the most serious concern. Evidence shows that different technological applications may lead to various learning outcomes, detrimental effects, even spoiling learning interest or motivations. Therefore, this paper is aimed not only to explore the multiple dimensions of recoding video clips in group (RVCIG) in learning English speaking skill but also illustrate how this activity (RVCIG) influences on learners' English speaking improvement. Apparently, these explorations and illustrations help to consider whether this RVCIG is widely used in teaching English speaking process or not. To do that, a quantitative research method with the tool of semi - structure interview is used to collect various information, mixed feedbacks or motivations from 2 groups of students fully participating in recording three video clips in group within course. Additionally, a questionnaire survey is also sent to 33 English learners for exploring both commendable and detrimental influences of this RVCIG on English speaking development. The findings indicate that RVCIG makes learners have various opposite experiences in language competence, confident expression, and communication, as well as cope with unavoidable challenges of time consuming, technological problems, and group member' disagreements. Whatever advantages or disadvantages of this RVCIG activity has, learners also express their interest and expectation of recording video clips in group for purposes of English speaking improvement, mutual engagement, collaborative learning and building friendship.
\end{abstract}

Keywords: multiple dimensions, recording video clip, English speaking skill, communication, language competence, confident expression

\section{Introduction}

To meet the requirement of the ASEAN (Association of Southeast Asian Nations) community in the 21th century, to catch up the speedy and abundant sources of informative and communicative systems, and to take the advantages of unprecedented mobility and the technological empowerment (A. Lian \& Pineda, 2014) as well, the suggestion of applying technological techniques in education is highly appreciated. Especially in the higher education environments, various technological applications are encouraged to use for reason of increasing autonomous learning for personal development and professional improvement. In this condition, learners, teachers, instructors and other staffs are required to adequately equip themselves various essential skills, profession knowledge to achieve high productivity at the work place, comfortably integrate in digital age, regional and international communities. In learning English language at universities, technological applications are advisable to apply for meeting the requirements of Decision 1400 "The Teaching and Learning of Foreign Languages in the National Education System Project 2020" issued by Vietnam government and obtaining the goals of National Foreign Language Project 2020 (also called Project 2020) established by Ministry of Education and Training (MOET) under the decision 1400 (Hashimoto \& Nguyen, 2018). To adhere the principles of the decision 1400 and the project 2020, the IT development and foreign language enhancement are compulsory in education institutes for reasons of attaining international English proficiency, technological advancement, academic knowledge accessing and cultural exchanging for competitiveness and integration of Vietnam nation in ASEAN community. This mission is also emphasized in the extend of National Foreign Language Project 2017 - 2005 when developing IT applications and investing more facilities in foreign language teaching and learning process are also reminded. It means that applying IT and technological techniques in English language training is the prior duty concerned and carried out. 
In reality, plenty number of researchers and educators ever expressed that learners are more successful in language learning if more technological advances or IT techniques are applied. This is illustrated by Lian (1991) when the strong support of CALL (Computer Aided Language Learning) (A. Lian, 1991) is exposed in language learning process. Lian has ever categorized the distribution system of computer software into four vital roles of (1) "as a teacher manager of learning" (tutorial of all kind in listening comprehension, grammar drill and practice); (2) "as a resource" (dictionaries, database, expert system such as dialogue generator and spelling helpers); (3)"as a tool" (word processing, spelling checkers, text analysis, accordance, desktop publishing); and (4) "as an and to communication" (Lian, 1991, p.2). This categorizing is the illustrations for the perspectives of the more technological applications used, the more open and flexible learning environments learners have and this also helps to increase the effectiveness of autonomous learning. Actually, learning autonomy is considered as an integral part of higher education environments. The undergraduates or post-graduates are obligated to teach themselves or autonomously access valuable knowledge and skills make more progress in their learning courses. Thus, it may conclude that applying more IT or technological techniques in language learning is indispensable because thanks to these techniques, more "tasked oriented, resources based learning network" are offered (A.-P. Lian, Thornquist, \& Thornquist, 1987) and learners are beneficial in autonomous language learning.

Although technological and IT applications are admitted to be beneficial to language teaching and language process, it is advisable to notice which technological technique is completely appropriate with the specific learning activities, learning objectives, learning outcomes, learning condition and learning history or background. Without the appropriate IT or technological applications, learners may have no adequate interest, motivations, and will power to carry out the teachers' instructions or project as requested. They even are under pressure or suffer from stress of overload learning. In addition, in the unprecedented and plentiful information, communication, mobility and technological empowerment (A. Lian \& Pineda, 2014), learners seems to have great awareness of focusing on learning what they really need, updating of news, flexible accessing academic learning materials, and taking in professional knowledge surrounded. Therefore, applying suitable technological techniques in teaching an English language class or skill is thoroughly concerned.

Based on the expression mentioned above, when taking in charge of teaching English speaking skill for freshmen with the major in English at Ho Chi Minh City Open University (HCMCOU) in form of face to face learning on campus, no sense of neither technologies or IT techniques is applied for reason of typical characteristics of speaking skill. Speaking skill is the way of producing language and speaking a language as English is an activity that requires using three communicative aspects of discussion, problem-solving, and role- playing (Oradee, 2012). It means that speaking English highly appreciate more direct contact, face to face communication and physical conversations in class. Thus, more opportunities or environments of practicing English, making dialogues or conversations, interacting with the teacher, classmates and other social relationships are suggested to create to compete English fluency instead of using technological technique.

Nevertheless, learners' English speaking ability is difficultly improved for series of inconvenient conditions including: time shortage in learning process, large size class, mixed English levels or inadequate English competency, unconsciousness of English learning importance, no habit of speaking English skill before, unfamiliar learning methods at university and some internal factors of learners such as being humble, shyness, scaring of losing face, anxiety, self-esteem, impatience, confidence shortage so forth. With such mentioned problems, the suggestion of recording video clips in group is compulsory to conduct with the expectation of learners' English speaking enhancement. Surprisingly, after a 10 week semester of recording three video clips in group, 33 freshmen expressed their interest and satisfaction in English speaking improvement when recording video clips in group (RVCIG) although numerous advantages and disadvantages of RVCIG are parallel existed within this process. For this reason, this paper is written to seek for the possible motivations of RVCIG, as well as exploring how beneficial or disadvantageous experiences that an English language learner obtained when video clips recorded in group as demanded. It is more important for whether or not this RVCIG activity is continuously applied in teaching other English speaking classes. The data collection and analysis of this quantitative research is chiefly based on the tools of semi structure interview to ask 2 groups of learners for their perception, feeling and feedbacks related to RVCIG and a questionnaire survey is also raised to 33 participants for getting responses related to benefits and 
drawbacks of this RVCIG technique applied in an English speaking class. The results shows that learners have various viewpoints and experiences of RVCIG. On the one hand, learners are advantageous in fields of language competence, speaking confidence and communicative ability when using RVCIG technique in English speaking skill. On the other hand, learners encountered some of barriers of time consuming, technological problems, and group member' opposite viewpoint. What matter learners face with- positive or negative in this RVCIG technique, they also reveal their interest and expectation of recording video clips in the next step for further English speaking practice to meeting learning objectives and building the social relationship (friendship).

The research questions mainly focus on:

1. What multiple dimensions do the learners experience when recording video clips in group?

2. What benefits do the learners obtain when more video clips recorded in group?

3. What challenges do the learners have to face with when conducting the activity of recording video clips in group?

4. How do the learners feel when recording a video clips in group? Why do learners expect to record more video clips in group when learning English speaking skill?

\section{Conceptual Framework}

Reply on the definitions of Cambridge Dictionary website, the concept of "multiple dimensions" is redefined as various similar or different features of an activity performed or something else existed in our world. "Multiple dimensions" in some cases is equal to "different dimensions" this is likely understood as "parallel universes" which is believed to be "alternate realities" and parallel existed in our own conditions but this may work or occur differently elsewhere (Futurism website, Dec, 2014) https://futurism.com/understanding-10-dimensional-universe)

The word video has the long history and its usefulness or effectiveness is asserted in different conditions of learners' comprehension of English language (Stempleski, 1987), contextualizing language (connecting between language form, meaning and culture) (Herron, Morris, Secules, \& Curtis, 1995), whereas, videotape strongly support for listening to native speakers voices, conducting daily interaction, making conversations and practicing vital linguistic structures. Learners are more interested in video technology for its visual functions which help to reduce ambiguous expression, avoid misunderstanding (thanks to visual images or natural communication), inspire foreign language learning, and create more authentic interaction (Qarabash, Heslop, Kharrufa, Balaam, \& Devlin, 2019). These exposed viewpoints seem to highly appreciate the application of video technology for learning English language skills.

Previous studies highly appreciate the benefits of video in a diverse fashion for its significant features, efficiency, and particular applications in specific contexts of each period. Many "visual literacy" and "multisensory medium" aspects (Swaffar \& Vlatten, 1997) are considered to be advantageous not only for learners in reading, listening, verbal comprehension, and observing speaking oral proficiency (Shinohara, 1997) but also for teachers in planning more strategies for integrating media in learning curriculum in order to meet overall learning objectives as planned (Swaffar \& Vlatten, 1997).Video technology is also applied to help learners in producing language, enhancing language assessment in a truthful and reliable way, giving more motivating and rewarding tasks with a clear, meaningful purpose and a concrete finished product (Biegel, 1998). Likewise, Shinohara (1997), Weyers (1999), Shrosbree (2008), asserted that learners' English speaking skill, confidence in speech expression, presentation skill, and public speaking are enhanced and improved if video-based instruction (Weyers, 1999) or videos in pair work and group work applied. Until 2009, various types of video segments and visual materials are acknowledged to be effective and widely used as the efficient teaching aids or useful educational tools, and the application of video recording is also origin from that (Hirata, 2009). Since video recording is exposed to be more advantageous, more activities of this video technology is widely used in teaching and learning process as Fadde et al. (2009) applied video editing activity in a "reflective teaching practice" course in different ways such as using videotaping for pre-service teaching as university supervisors, applying self-directed video review for supporting writing reflective lesson analysis, selecting and editing video vignettes for illustrating written reflection purpose, and posting of video vignettes on electronic portfolio pages for further studying or discussion (Fadde, Aud, \& Gilbert, 2009). In 2011, a video of classroom activities is recoded, and various techniques of recording 
video applied to record a lecture highlighting both the advantages and disadvantages of each for purpose of improving learners' lecture comprehension (Odhabi \& Nicks-McCaleb, 2011). This video reflection is considered as productive method for its fixative property with flexible functions of recording, saving, and reproducing information when needed (Suwartono, 2014). Applying video also contribute to improve learners' pronunciation when integration into communicative activities (Suwartono, 2014). Another demonstration of ESL learners successful in recording digital video when they have more opportunity to submit script drafts, voice recording demos, visual image gathering, as well as receiving feedbacks for their writing, speaking ability and course content application. It means that learners have chance to expression themselves and support other learners through giving feedbacks via a classroom social media platform (Alley-Young, 2017). Recently, Teng (2019) also expresses the agreement of vital role of videos captioned and the strategy of advance-organizer for L2 primary learners in collocation learning (Teng, 2019). These explain for the reason why recording video is indispensable and continuously used in wide range of training and education.

Actually, video technology or technique are highly appreciated in language learning, it is more valuable and meaningful if only video technology or technique is applied in the real and practical activity of langugage learning such as recording videos in pairs or groups. Evidence shows that Shrosbree, (2008) applied video pair -work assessment to asssess the oral performances of learners actitvity of video-recorded pair work and this video technological application is considered as the most interesting and appealling leanguage learning activity because learners have more chances to speak to their peers (symmetric discourse), rather than a teacher/assessor (asymmetric discourse) (Shrosbree, 2008). Similarly, it is also suggested to record video clips in group in language learning process for reason of multiple experiences obtained. Numerous researchers admitted that the effectiveness of collaborative learning is highly appreciated in aspects of higher levels of thinking, problem-solving development (Michaelsen, Fink, \& Knight, 1997), as well as the higher mutual engagement, discussion and making decision. Whenever learners and their peers have working collaboration, more particular learning environment are provided due to more social situation maintained and more natural communication occurred (Roschelle \& Teasley, 1995). These expressions are completely supportive for applying videos in teaching English speaking skill.

Despite the fact that a variety of previous studies related to the indispensability of the video technological industry and its diverse benefits and drawbacks in education environment are obviously illustrated, recording video clip in group for English speaking improvement and its multiple dimension is still limited in discussion. Hence the suggestion of this topic is proposed

Recording video clips in group is defined as a learning activity which learners are put in a group of 5 to 6 people, and required to have good collaboration to create productive and completed video clips. With the strong support of digital technology, learners are allowed to easily and comfortably produce the quality video clips without concern of technological aspect. But the most worried and problematic issue is the content of video clips created. Learners are obligated to embed themselves in this collaborative video clip recording through discussing, arguing and making final decision for the purposes of creating the most qualified video clips and maintaining their collaborative team work or friendship.

Multiple dimensions of recording video clip in group is known as numerous converse aspects parallel existed in process of video clip recorded. These may be some disadvantages consist of: (1) a large plenty of time invested in filming and editing work (Shrosbree, 2008); (2) technological problems (including both technological advances or devices and technological techniques as editing, recording and subtitling and so on), together with several stages of management video project (such as selecting video, cropping and muting scene, discussing and presenting video targets, group listening comprehension (or scenario creation) activities, individual practice, group rehearsal and soundtrack dubbing (Burston, 2005); (3) and other factors of group identity and formation, group members' attitude, perception, awareness, and coordination (Jacucci, Oulasvirta, Salovaara, \& Sarvas, 2005). These are also some advantages in language competence, communication and confident expression exposed English speaking process including: listening and verbal comprehension, vital linguistic structures, oral proficiency, interactive and conversational ability and some benefits of reducing ambiguous expression, avoiding misunderstanding in communication, motivating foreign language learning, creating authentic interaction (Qarabash et al., 2019). 


\section{Research Methods \\ Research setting}

Taking responsibility for teaching an English speaking class level 1 for the English major freshmen at HCMCOU, series of challenges that learners have to face with including time shortage in learning process (45 periods within a semester), large size class (33 learners), mixed English levels or inadequate English competency (entered university with English competency at A 1 or A 2 while MOET requirement of graduates at $\mathrm{C} 1$ level of CEFR (Council of Europe's Common European Framework of Reference) standard, inadequate consciousness of English learning importance (just enough scores for passing the entrance university examination at HCMCOU), no habit of speaking English skill at high schools, and new learning methods at university academic, and other internal reasons derived from learners' conservative thoughts of newcomers, being humble, avoiding showing off themselves, staying in space with strangers, scaring of losing face, as well as some natural and uncontrolled feelings of anxiety, self-esteem, impatience, confidence shortage so forth. Such these problems cause barriers in English speaking skill. The facts shows that learners in this speaking class attend 45 periods face to face on campus within 10 weeks for listening and speaking skill level 1, learners have inadequate time to practice speaking in the classroom. Learning in the crowded class, learners have no opportunity to take better care from the teachers, they are unconscious about their strength or weaknesses in learning process. A speaking class with mixed English levels of learners causing problem of using appropriate teaching methods for all learners. Additionally, learners' characteristics also influence on English speaking ability. Most learners are young (at the age of $18-22$ ) and in process of being adults and perfecting their personality (some express as their maturity but others may not, this lead to various learning styles, learning methods and learning outcomes. Learners have different strengths, weaknesses and interest in three subjects as Mathematics, Literature, and English (though they pass university entrance examination but not sure they have potential in English skills). Learners also have different living condition ( majority of learners are from many provinces, some are from big cities), different in education background (diverse high schools with various training quality), different financial background (some are in rich/average/ low income condition), family background (crowded/ large family or small family with less or more siblings, more or less responsibilities), cultural background (diverse rituals/ customs), family cultural background (morality, humanity, communicative and interactive abilities, living styles). All these factors greatly influence on learning quality at school and extensive learning or learning autonomy in aspects of learning investment, learning conditions and learning motivations and determination.

With such problems mentioned above, the author have no way to help learners improve their English speaking ability if no technological advances and IT techniques used. Thus, the decision of recording video clips in group is issued with the clear instructions, deadline and marking scheme presented. Apparently, this decision is based on some advantages of video technology. It is supposed that if learners recording video clips in group, learners have opportunities in repetitive learning process. It means that learners can record, revise, review or replay the video clips until they achieve their learning goals. Furthermore, most learners are the young ones (18 -22 years old), born in the digital age, they are easily take in this new technological technique and feel more interested and comfortable when technology-based learning is applied. Learners may have more opportunities to work with their classmates and necessary values attained such as collaborative learning, teamwork, friendship and so on.

\section{Research tools and participants}

A quantitative research conducted to explore multiple dimensions of recording video clips in group and two opposite sides (commendable contributions and detrimental influences) of this activity are also discovered to thoroughly understand whether this RVCIG will be progressively applied for future teaching English speaking skill in a face to face learning setting or not. To collect the data for data analysis purpose and exploring the research findings, two typical research tools are used.

The first research tool is semi- interview structure with the designed open- ended questions, and directly interview 2 groups of English major freshmen (out of 5 groups of in total of 33 learners). The participants in these two groups are learners who fully participate in recording three video clips per a 10 week semester and meet all requirements of the teachers. The group selection is based on typical characteristics of members in each group. Two these groups is called mixed groups for their diverse learning background and learning 
conditions. Five members of each group are categorized in 3 sub-groups of English levels including a subgroup of good English speakers, average English speakers, and less able English speakers. All these speakers of each group living in either big cities or provinces, they are experienced the same MOET English learning programs at high schools but they achieve different English levels for their different learning backgrounds and learning conditions. If learners have more investment in extensive English language learning at Foreign Language Center and have environment or habits of speaking English, they may be good or average speakers while less able speakers are merely focus on MOET English learning at high schools for purpose doing tests more than communication. Learners are required to record video in a mixed group of English levels and mixed personal background for plenty of reasons: (1) learners are freshmen (newcomers at university, they haven't known each other or become friends before) they are easily successful in learning collaboration (work well together) with all respect, self-esteem, careful treatment, keeping space in contact and even, having great consciousness of obey regulations; (2) whenever learners have better collaborative learning they comfortably mutual engage in learning materials and learning activities and these are beneficial to language competence, confident expression and better communication and this leads to English speaking improvement; (3) Once learners achieving their learning goals or learning objectives they are easily to overcome unexpected challenges such as time consuming, technological problem, or dis agreement among members; (4) learners have more opportunities share or study together when mixed English speakers are put together (good speakers feel interested in expressing their leadership in group while less able speakers are excited when they have chances to study from the better). Whatever learning purposes are exposed, the most concern is that teachers need to have clear instructions, marking scheme and explanations for learning objectives obtained, and beneficial learning outcomes because learners refuse doing something without learning aims, targets achieved.

The second tools is questionnaire survey which is directly handed out to 33 students at the final session of this speaking skill course with the aims of getting feedbacks, attitudes, and feelings and perceptions of learners when recording video clips in group within learning course. Actually, these 33 learners are dived into 6 groups and they freely select their group members to assure that they have similar characteristics, interest and convenient conditions for collaborative learning, meeting demands of the learning course and improving their English speaking capability. Despite learners are optional in choosing their group members, it is advisable to have mixed English levels and diverse talents of technological techniques, content editing or organizing the event of recoding video clips. Overall, 6 groups complete their video clips in different manner and the quality of each video clip is varied, but these groups are appreciated for their performances, team spirit and learning collaboration for meeting general learning demands and learning outcomes of English speaking enhancement.

After more than 2 hours of interviewing 10 learners in two typical groups and getting responses of 33 learners in an English speaking class, the data analysis is carried out afterwards through grouping interview answers and using SPSS software to analyze responses collected (based on Likert 6 point scales) to seek for the research findings. 


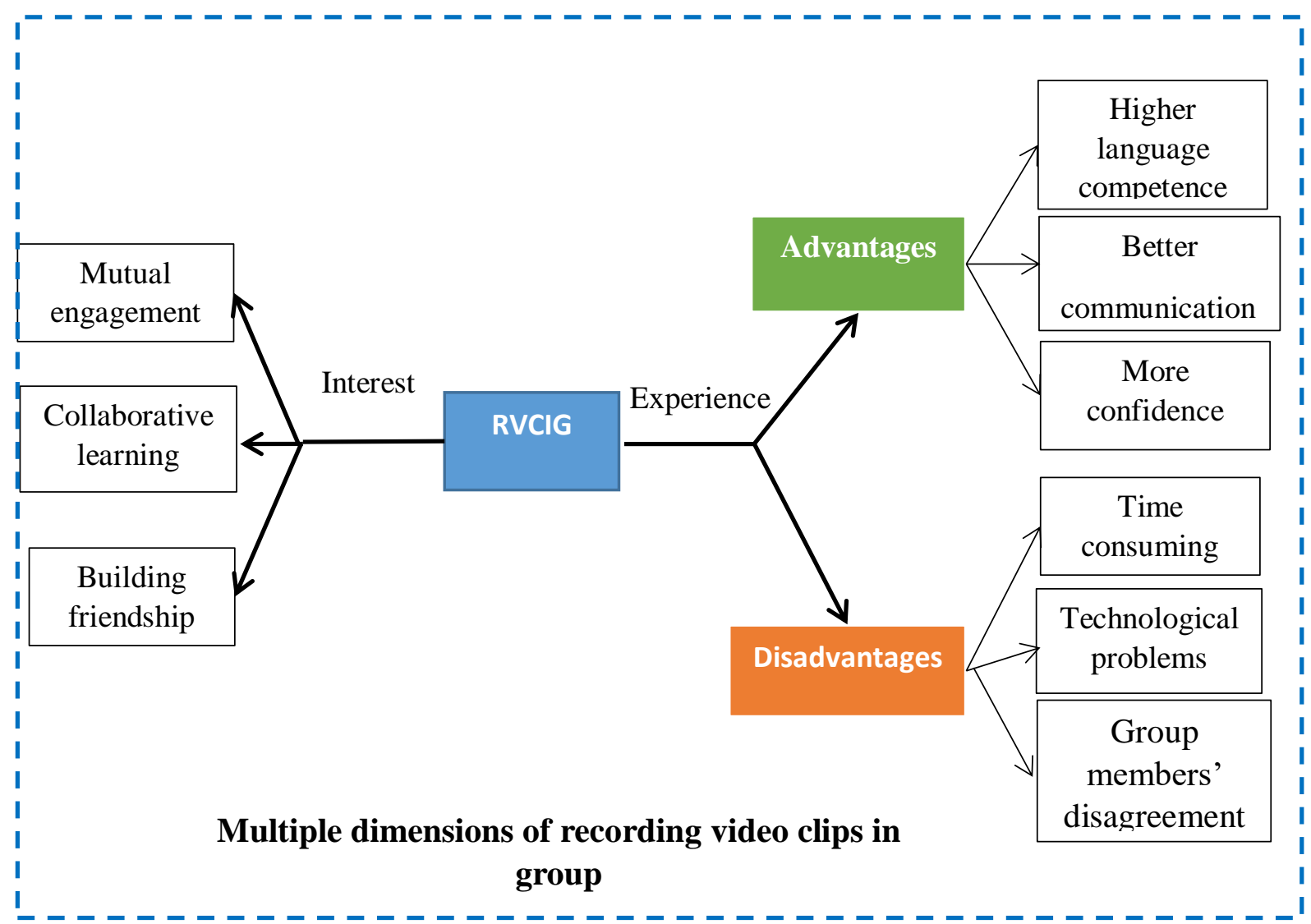

\section{Research design}

Based on the research design, four hypothesizes are taken into account:

- Hypothesis 1 - Learners experience various commendable and detrimental faces when recording video clips in group

- Hypothesis 2 -There are various benefits learners obtained when more video clips are recorded in group including higher language competence, the more confidence expressed, and the better communicative attained

- Hypothesis 3 Learners are unavoidable to cope with challenges of time consuming, technological problems and disagreement among learners when the activity of recording video clips in group conducted.

- Hypothesis 4 - Whatever advantages and disadvantages experienced, learners are

\section{FINDINGS AND DICUSSION}

In this part, the general information of 33 participants in this research and the statistics of their responses to the questionnaire survey are presented. Also, the interviewing questions raised to 2 groups of typical learners taking part in the RVCIG activity and their responses are displayed as well. These expressions and performances are aimed to analyze and illustrate four hypothesizes proposed to response to the research questions exposed.

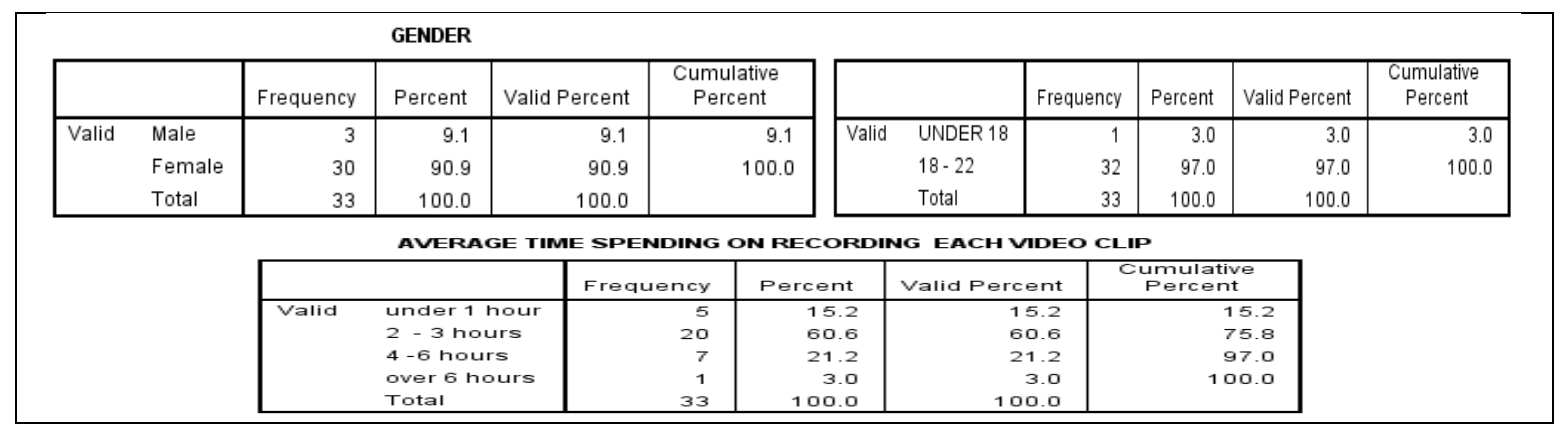




\begin{tabular}{|c|c|c|c|c|c|c|c|c|c|c|c|}
\hline \multicolumn{6}{|c|}{ MEMBERS OF EACH GROUP PARTICIPATING IN RECORDING VIDEO CLIPS } & \multicolumn{6}{|c|}{ NUMBER OF VIDEO CLIPS RECORDED } \\
\hline & & Frequency & Percent & Valid Percent & $\begin{array}{c}\text { Cumulative } \\
\text { Percent }\end{array}$ & & & Frequency & Percent & Valid Percent & $\begin{array}{c}\text { Cumulative } \\
\text { Percent }\end{array}$ \\
\hline \multirow{4}{*}{ Valid } & 3-4 mmbers & 5 & 15.2 & 15.2 & 15.2 & \multirow[t]{4}{*}{ Valid } & One videoclip & 1 & 3.0 & 3.0 & 3.0 \\
\hline & $5-6$ members & 27 & 81.8 & 81.8 & 97.0 & & $2-3$ video clips & 30 & 90.9 & 90.9 & 93.9 \\
\hline & over 8 members & 1 & 3.0 & 3.0 & 100.0 & & more than 7 video clips & 2 & 6.1 & 6.1 & 100.0 \\
\hline & Total & 33 & 100.0 & 100.0 & & & Total & 33 & 100.0 & 100.0 & \\
\hline
\end{tabular}

\section{General information related to the activity of recording video clips in group}

The figure1 indicates that 33 research participants are almost females (more than 90\%). They are first year university student (97\% of them are at the age of 18 to 22). They belong to an English speaking class that has face to face learning on campus setting. Due to time limits and some limitations in English proficiency and learning outcomes, these learners are require to record the video clips in group with the expectation of improving their IT techniques and English speaking ability to integrated the modern society. 33 learners are require to work in group of at least 3 - 4 members and no more than 7 to 8 for reasons of flexible selecting partners that have the same learning interest and personality to assure good learning collaboration and effectiveness (work together to record the high qualified and meaningful video clips). More than $80 \%$ learners work in group of 5 to 6 members and record $2-3$ video clips per semester (90.9\%) according to the statistics. These number prove that learners obey the requirements of the teacher to attain the learning goals as planned.

\section{Response for research question 1: What multiple dimensions do the learners experience when recording video clips in group?}

Hypothesis 1 is supposed - Learners experience various commendable and detrimental faces when recording video clips in group

This hypothesis 1 is illustrated and analyzed based on the responses of ten interviewees who are the English major freshmen in an English speaking class at HCMCOU and they are also the eye witnesses and thoroughly experience all stages of recording video clips in group.

When these following interview questions are asked, ten interviewees explain in different way but in general they agree that "Recording video clips in group is the most effective activity among other activities inside or outside the class" Because learners not only have more experiences in academic learning environments as schools or university (take in knowledge through language learning, language competence, practice speaking skill), but also comprehend other experiences and skills from community thanks to collaborative learning, technological based learning, and learn more other vital life skills (softs-kills). Learners know how to wellbehaved with their partners, consider the effective ways to negotiate for achieving the goals as set, or have chance to sharpen their problem solving skill whenever encountering disagreements or argument occurred. Learners have more chance to challenge themselves through being humble or showing off themselves when necessary, learn more way to control some uncontrolled feelings of anxiety, embarrassment, losing face and so forth. Relying on more learning collaboration, or group work cooperation, or project based learning such as recording video clips in group in learning English speaking skill, learners obtain numerous valuable academic knowledge of language competence (more vocabulary accessed, more grammatical structures consolidated, more ideas or discourse analysis obtained), as well as more communicative skill improved (learners are more professional in discussing, negotiating and problem solving skills to achieve the planned targets). Obviously, the knowledge and skills learners obtained, the more confidence in English language expression exposed, the more personal performances are illustrated, and the more anxious or embarrassed feelings controlled. However, to attain the peak of these experiences, learners have to embed themselves in various challenging environments, encounter unexpected conditions and situations, or even "taste mixed flavors" when contacting with group or team members (some disagreements or argument happened) or coping with troubles teamwork or group work activities (unfamiliar with techniques and skills of speaking English in front of the public and image captured when video clips recorded in group). Overall, learners have to go through two concerned opposite sides or feelings of a matter displayed because it seems to be negative in this field but in the other side, it is positive and highly appreciated. The obvious evidence demonstrated that when the RVCIG activity required learners have to practice and re- practice speaking skill many times before recording video clips, but after having a rehearsal, it is not good or ideal as expected, the 
decision recording video clip again is required. Honestly, it is terrible with time consuming, energy investment, or uncomfortable feeling suffered and so on. But it is beneficial to learners when they have more chances to being with friends. Whatever bitter experience they have, it is undeniable that they have unforgettable memory when more qualified video clip recorded, and their learning goals obtained (meet the requirement of the teacher). These explain for the reason why learners have "multiple dimension when recording video in group". Apparently, all these expression are proved based on the revealing or sharing of learners in the interview and data collected from the questionnaire survey as follow:

Interviewing question 1: Between some speaking activities happened in the classroom (such as group work discussion, pair work conversation, and presentation in in front of class) and some other activities outside the class (such as doing online exercise on LMS and recording video clips in group), What activity is the best one that makes you (learners) more improve your English speaking ability? Why?

\section{Answer of question 1:}

- Learn a lot (both language skill and other soft skills), meet friends together for discussing video clip content, recording video clip techniques, sharing ideas, giving feedbacks or comments to other classmates and conversely receiving feedbacks or comments), have more confidence and relaxation to speaking with friends more than talking or speaking to the teachers, have chances to wear beautiful clothes and making up (because of recording our own images) (Ms Duyen said)

- Improve our English speaking skill such as pronunciations, vocabulary, language functions, and fluency because when any our classmates have wrong pronunciation group members correct and ask to re-pronounce. For vocabulary, we listen to peers' expression / speaking but sometimes not understand, I take note and then ask him/her other group members learn more words and remember those words for long because learn in context), adjust their behaviors (not perform confidently physical manners, movement, posture or doing something unusual, group member give comment and ask to re-do or re-perform. Record again that part of clip change ourselves), be less under pressure ( work with friends- more relaxed, and because of do again / practice again leading to being skilled so not being stress), get more confidence thanks to practice in both verbal language and nonverbal language (Mr Kiet exposed)

- To have happiness (working with classmates, change atmosphere (recording video clip in different places in coffee or in the park)/ change time and space depending on the decision of all group members). Have good preparation just speaking based on memorization, not natural enough, have habit of practice speaking to record video clips, but lack of quick speedy reflection English preparation for, improve English fluency, develop mutual engagement in learning materials and involvement with peers ( $\mathrm{Mr}$ Minh revealed)

- Access more ideas from partners' answers, get more comments / feedbacks ideas (Ms Nhu expressed)

- To discuss or even easily argue for what / how should be done (various people have diverse perspectives, easily to cause disagreement, annoyed felling may cause team spirit), to have more happiness for new learning styles (not record video clip before), enjoy the strange experiences in different time and space (without recording video clips, no chance to visit other places), have unforgettable memory (when review video clip), to be more creative ( recording a video of TV talk show clip (Ms Mai Thi emphasized)

- To capture our images, have more interaction environment, more face to face contact, more argument and lead to more meaningful learning method (learning in real context, learning from friends in a lively environment or condition this lead to easily to access knowledge)(Ms Nga shared)

- Have better language expression and non-verbal performance, to be more active in 


communication and interaction (Mr Chuong stated)
- To learn skill of good preparation, to be more patience to practice again and again
until complete our roles (Ms Dung reveal )
- $\quad$ Know how to overcome some uncontrolled physical conditions (a shame feeling,
losing face) (Ms Phuong)
- To practice, re-practice, play - re play, view and review and to adjust ourselves in
English speaking skill, language ability and personality or physical appearance
and performance (Ms Tien)
Interviewing question 2: Do you think that recording video clip in group is a great
challenge for you? Why?
Answer of question 2:
All 10 interviewees exposed that recording video clips in group is definitely
challenging for reasons of taking much time to prepare the facilities (sound, light,
wi-fi connection.), technological advances (mobile phone, camera...), and facing
with troubles of technological techniques in recording, editing... and even with the
challenges of learners performances in verbal language and non- verbal language
are also included.
Learners also revealed that they need to be adequately patient and willing to have
numerous repetitive in recording video clip process if something unexpected
happened.

Likewise, the responses of research participants from the questionnaire survey is also a helpful and meaningful evidence because when learners are asked about the level they participated in this RVCIG activity. The statistics in figure 2 illustrated that more than 90\% (measured from levels of "quite agree, agree and totally agree) research participants express their agreements on what they have done, contributed or experienced to the RVCIG when recording video clips in group including:

- Learners have more opportunities to participate in group and discuss about the content of the video clip (97\%). A recorded video clip is meaningless if no interesting ideas are logically organized or presented appropriately

- Learners have chance to express themselves when actively contribute their ideas to video clip content $(100 \%)$

- To have good ideas learners actively search information and access more learning materials for video clip content supporting $(96.9 \%)$

- Learners also participate in discussion to select the good ideas or viewpoints (among plenty of opinions raised by group members) to build video content (100\%)

- Learners participate in organizing the ideas in order to ensure create an interesting of video content $(100 \%)$

- Learners participate in proof reading and editing the video clip content (94\%)

- Learners have chances to naturally communicate with group members (94\%)

- Whenever learners are in troubles they definitely receiving the supports of group members (93.9\%)

Throughout this data analysis, it is easily recognized that learners engage in diverse activities and these help to enrich their academic knowledge and language competence. Also, through this contacting with group members and getting their supports strongly support for the successful communication and confident expression in group. Obviously, to attain these qualifications, learner have to experience various sweet and bitter flavors in such collaborative video clip recoding. Thus, it could be concluded that learners have multiple dimensions of RVCIG. 


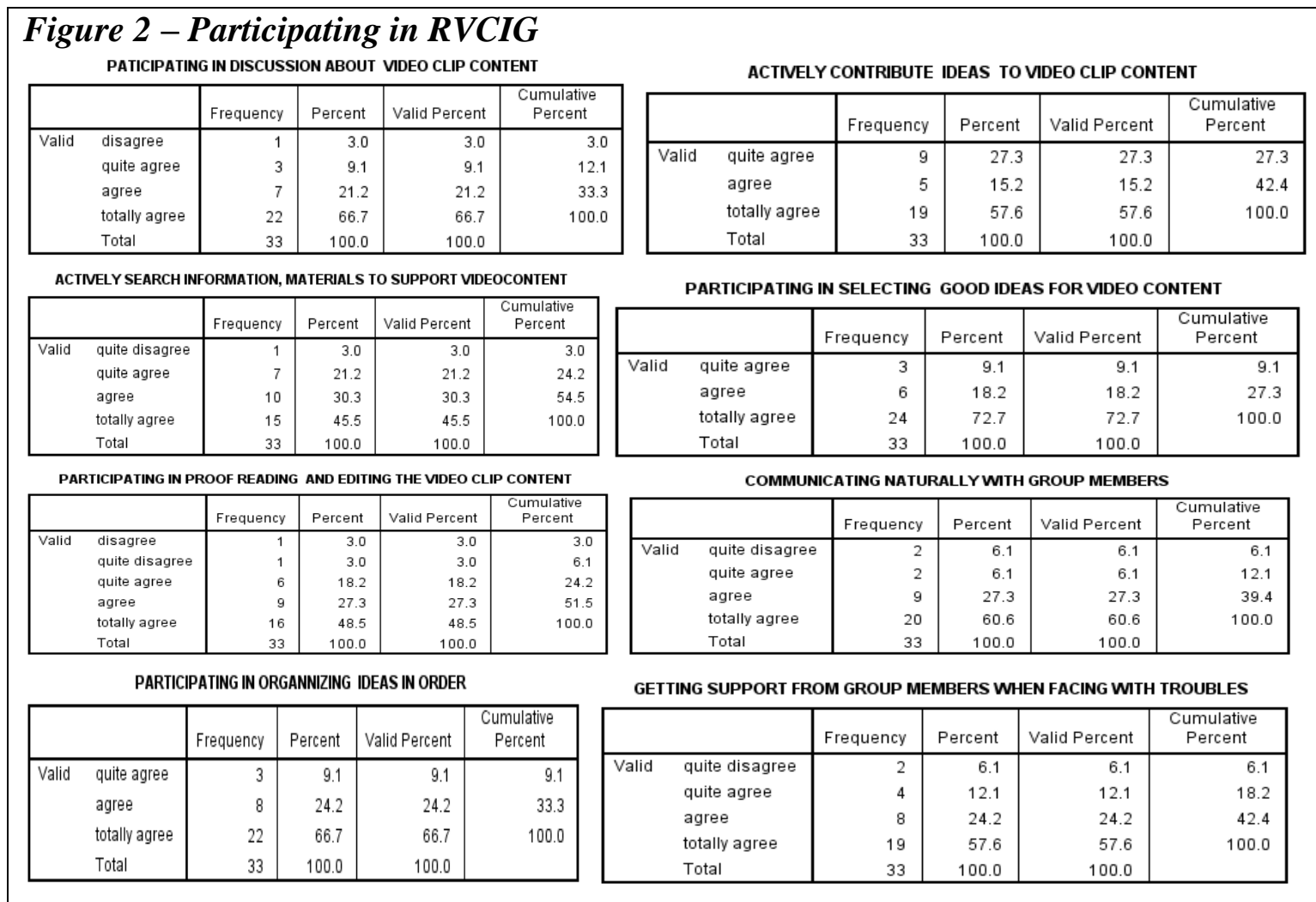

\section{Response for research question 2: What benefits do the learners obtain when more video clips recorded in group?}

Hypothesis 2 -There are various benefits learners obtained if more video clips are recorded in group including higher language competence, the more confidence expressed, and the better communicative attained. These are exposed when more interviewing questions are asked and more responses from the survey displayed

Interviewing question 3 - Do you know the reasons why the teacher require you to record video clips in group instead of recording video clips individually when learning English speaking skill? Answer of question 3 -

Ten of interviewees express their prediction of with the following explanations:

When recording video clips in group learners are obligated to work well together. It means that learners need to have good cooperation during the stages of recording video clips such as discussing for content focus, writing draft, editing, proofreading, rehearsal, rewriting, reediting if they want to produce a video clip products.

Whenever learners have good collaborative learning, learners have more chances to access more knowledge, listen to group member' ideas, sharing or exchange viewpoints.

Whether learners are successful in working in group as expected or not, learners also have opportunities to look back themselves and recognize what their strengths or limitation they have and nee find out the solutions for their own improvement.

Once learners positively cooperate with their classmates/ peers, various benefits obtained such as increasing teamwork spirit, developing language competence (learning more vocabulary, grammatical structure etc. to ensure that learners are more professional in language expression thanks to getting feedbacks more correction of pronunciation and language usage).

Working in group helps learners communicate more naturally when getting feedbacks and comments from their peers and this help to avoid some bad habits in both verbal language and non- verbal language

Thanks to recording video clips in group, learners become more professional when obeying group principles, punctuality, and more responsible for what they do when being group member. 
In case of doing something wrong or inappropriate, feeling of embarrassment, disappointment, or losing faces help them make more effort to catch up the pace of their friends and this makes great progress in learning process

Replying on the answers of interviewees, learners seems to clearly understand the importance of RVCIG despite the raised interviewing question is not directly asked for the advantages or benefits of RVCIG. As learners expressed or mentioned above, whenever learners have learning collaboration (such as RVCIG), learners are obligated to spend time together to engage all activities suggested to complete their individual responsibilities and team mission as planned. Certainly, when involving in group, learners have to consider what they should do, how do they perform or behave in group, when they need to negotiate or make decisions in order to they do not harm the general benefits of a group or losing their rights when integrating in group or community. These are strongly supportive for the maturity of learners not only in academic profession such as language competence (with series of stuffs pronunciation, vocabulary, language structure when using English in recoding video clips with suggested English topics) or IT techniques (learn more techniques of recording, editing, exporting video file etc.), but other soft skills of communication, interaction, or confidence expression.

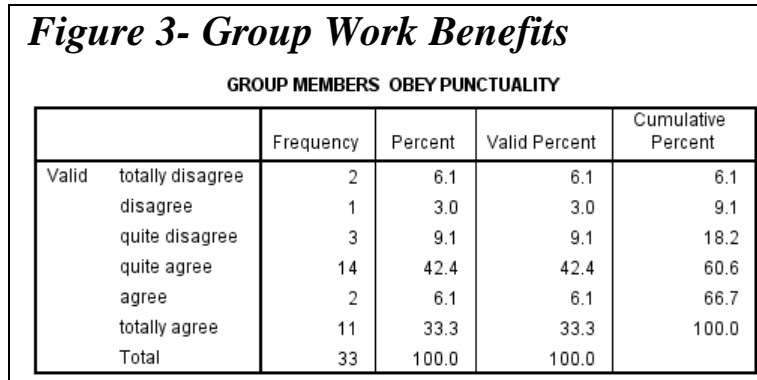

GROUP MEMBERS HAVE GOOD LEARNING COLLABORATION AND COOPERATION

\begin{tabular}{|c|c|c|c|c|c|}
\hline & & Frequency & Percent & Valid Percent & $\begin{array}{c}\text { Cumulative } \\
\text { Percent }\end{array}$ \\
\hline \multirow{6}{*}{ Valid } & disagree & 1 & 3.0 & 3.0 & 3.0 \\
\hline & quite disagree & 2 & 6.1 & 6.1 & 9.1 \\
\hline & quite agree & 4 & 12.1 & 12.1 & 21.2 \\
\hline & agree & 9 & 27.3 & 27.3 & 48.5 \\
\hline & totally agree & 17 & 51.5 & 51.5 & 100.0 \\
\hline & Total & 33 & 100.0 & 100.0 & \\
\hline
\end{tabular}

GROUP MEMBERS ARE WILUNGNESS TO SHARE IDEAS, GET FEEDBACKS AND COMMENTS AND COOPERATION TO COMPLETE DUTIES / GOALS
GROUP MEMBERS SUPPORT TOGETHER WITH GOOD ATTITUDES

\begin{tabular}{|c|c|c|c|c|c|}
\hline & & Frequency & Percent & Valid Percent & $\begin{array}{c}\text { Cumulative } \\
\text { Percent }\end{array}$ \\
\hline \multirow[t]{6}{*}{ Valid } & disagree & 2 & 6.1 & 6.1 & 6.1 \\
\hline & quite disagree & 1 & 3.0 & 3.0 & 9.1 \\
\hline & quite agree & 4 & 12.1 & 12.1 & 21.2 \\
\hline & agree & 6 & 18.2 & 18.2 & 39.4 \\
\hline & totally agree & 20 & 60.6 & 60.6 & 100.0 \\
\hline & Total & 33 & 100.0 & 100.0 & \\
\hline
\end{tabular}

GROUP MEMBERS HAVE GOOD AWARENESS OF THEIR RESPONSIBILITIES OF INVIDUAL WORK AND GROUP WORK

\begin{tabular}{|c|c|c|c|c|c|}
\hline & & Frequency & Percent & Valid Percent & $\begin{array}{c}\text { Cumulative } \\
\text { Percent }\end{array}$ \\
\hline \multirow[t]{5}{*}{ Valid } & disagree & 1 & 3.0 & 3.0 & 3.0 \\
\hline & quite agree & 6 & 18.2 & 18.2 & 21.2 \\
\hline & agree & 8 & 24.2 & 24.2 & 45.5 \\
\hline & totally agree & 18 & 54.5 & 54.5 & 100.0 \\
\hline & Total & 33 & 100.0 & 100.0 & \\
\hline
\end{tabular}

GROUP MEMBERS COMMITE TO WORK IN A PROFESSIONAL AND PRECISE FASHION

\begin{tabular}{|c|c|c|c|c|c|}
\hline & & Frequency & Percent & Valid Percent & $\begin{array}{l}\text { Cumulative } \\
\text { Percent }\end{array}$ \\
\hline \multirow[t]{6}{*}{ Valid } & disagree & 2 & 6.1 & 6.1 & 6.1 \\
\hline & quite disagree & 2 & 6.1 & 6.1 & 12.1 \\
\hline & quite agree & 4 & 12.1 & 12.1 & 24.2 \\
\hline & agree & 8 & 24.2 & 24.2 & 48.5 \\
\hline & totally agree & 17 & 51.5 & 51.5 & 100.0 \\
\hline & Total & 33 & 100.0 & 100.0 & \\
\hline
\end{tabular}

\begin{tabular}{|c|c|c|c|c|c|}
\hline & & Frequency & Percent & Valid Percent & $\begin{array}{c}\text { Cumulative } \\
\text { Percent }\end{array}$ \\
\hline \multirow[t]{6}{*}{ Valid } & disagree & 2 & 6.1 & 6.1 & 6.1 \\
\hline & quite disagree & 1 & 3.0 & 3.0 & 9.1 \\
\hline & quite agree & 6 & 18.2 & 18.2 & 27.3 \\
\hline & agree & 10 & 30.3 & 30.3 & 57.6 \\
\hline & totally agree & 14 & 42.4 & 42.4 & 100.0 \\
\hline & Total & 33 & 100.0 & 100.0 & \\
\hline
\end{tabular}

GROUP MEMBERS HAVE STRONG DETERMINATION AND PATIENCE ENOUGH MHEN ACCEPTING RECORDING MDEO CLIPS MANY TIMES

\begin{tabular}{|c|c|c|c|c|c|}
\hline & & Frequency & Percent & Valid Percent & $\begin{array}{c}\text { Cumulative } \\
\text { Percent }\end{array}$ \\
\hline Valid & $\begin{array}{l}\text { quite disagree } \\
\text { quite agree } \\
\text { agree } \\
\text { totally disagree } \\
\text { Total }\end{array}$ & $\begin{array}{r}1 \\
3 \\
4 \\
25 \\
33 \\
\end{array}$ & $\begin{array}{r}3.0 \\
9.1 \\
12.1 \\
75.8 \\
100.0 \\
\end{array}$ & $\begin{array}{r}3.0 \\
9.1 \\
12.1 \\
75.8 \\
100.0 \\
\end{array}$ & $\begin{array}{r}3.0 \\
12.1 \\
24.2 \\
100.0\end{array}$ \\
\hline
\end{tabular}

Similarly, the responses of 33 learners in English speaking class are also the proofs of more benefits learners obtained in many aspects of profession and other social skills when group members work together with the great awareness, attitude, responsibilities etc. in this RVCIG activity. The figure 3 illustrated as follow:

- $\quad$ Group members obeying regulations of punctuality (81\%)

- Group members support together with the good attitudes (98\%)

- Group members have good learning collaboration and cooperation to produce the quality video clips (93.9\%)

- Group members have good awareness of their responsibilities of individual work and group work $(96.9 \%)$ 
- Group members are willingness to share ideas, get feedbacks and comments, and have good cooperation to compete their duties or goals as planned $(88.5 \%)$

- Group members commit to work in a professional and precise fashion (90.7\%)

- Group members have strong determination and patience enough when accepting to re-recording the video clip many times. (97\%)

The figure 4 also indicate that good collaboration in RVCIG of group members leading to great benefit as follow:

\begin{tabular}{|c|c|c|c|c|c|}
\hline \multicolumn{6}{|c|}{$\begin{array}{l}\text { Figure 4- Benefits } \\
\text { COMPLETE RECORDING VIDEO CLIP ON TIME }\end{array}$} \\
\hline & & Frequency & Percent & Valid Percent & $\begin{array}{c}\text { Cumulative } \\
\text { Percent }\end{array}$ \\
\hline \multirow[t]{5}{*}{ Valid } & disagree & 1 & 3.0 & 3.0 & 3.0 \\
\hline & quite agree & 5 & 15.2 & 15.2 & 18.2 \\
\hline & agree & 4 & 12.1 & 12.1 & 30.3 \\
\hline & totally agree & 23 & 69.7 & 69.7 & 100.0 \\
\hline & Total & 33 & 100.0 & 100.0 & \\
\hline
\end{tabular}

LEARNERS IMPROVE THEIR ENGLISH PRONUNCIATION, VOCABULARY AND

\begin{tabular}{|c|c|c|c|c|c|}
\hline & & Frequency & Percent & Valid Percent & $\begin{array}{c}\text { Cumulative } \\
\text { Percent }\end{array}$ \\
\hline \multirow[t]{4}{*}{ Valid } & quite agree & 6 & 18.2 & 18.2 & 18.2 \\
\hline & agree & 7 & 21.2 & 21.2 & 39.4 \\
\hline & totally agree & 20 & 60.6 & 60.6 & 100.0 \\
\hline & Total & 33 & 100.0 & 100.0 & \\
\hline
\end{tabular}

\begin{tabular}{|c|c|c|c|c|c|}
\hline & & Frequency & Percent & Valid Percent & $\begin{array}{c}\text { Cumulative } \\
\text { Percent }\end{array}$ \\
\hline \multirow[t]{7}{*}{ Valid } & totally disagree & 1 & 3.0 & 3.0 & 3.0 \\
\hline & disagree & 1 & 3.0 & 3.0 & 6.1 \\
\hline & quite disagree & 2 & 6.1 & 6.1 & 12.1 \\
\hline & quite agree & 7 & 21.2 & 21.2 & 33.3 \\
\hline & agree & 5 & 15.2 & 15.2 & 48.5 \\
\hline & totally agree & 17 & 51.5 & 51.5 & 100.0 \\
\hline & Total & 33 & 100.0 & 100.0 & \\
\hline
\end{tabular}

LEARNERS EXPRESS ALL THEIR ROLES WHEN WORKING IN GROUP (COMPLETE INDIMIDUL WORK, SUPPORT OTHER CLASSMATES, GIVING FEEDBACK,

\begin{tabular}{|c|c|c|c|c|c|}
\hline & & Frequency & Percent & Valid Percent & $\begin{array}{c}\text { Cumulative } \\
\text { Percent }\end{array}$ \\
\hline \multirow[t]{4}{*}{ Valid } & quite agree & 4 & 12.1 & 12.1 & 12.1 \\
\hline & agree & 10 & 30.3 & 30.3 & 42.4 \\
\hline & totally agree & 19 & 57.6 & 57.6 & 100.0 \\
\hline & Total & 33 & 100.0 & 100.0 & \\
\hline
\end{tabular}

LEARNERS GET MORE BENEFITS IN ENGLISH LANGUAGE COMOETENCE, CONFIDENCE IN ENGLISH SPEAKING AND BETTER COMMUNICATE MNTH PEERS

\begin{tabular}{|c|c|c|c|c|c|}
\hline & & Frequency & Percent & Valid Percent & $\begin{array}{c}\text { Cumulative } \\
\text { Percent }\end{array}$ \\
\hline Valid & $\begin{array}{l}\text { quite disagree } \\
\text { quite agree } \\
\text { agree } \\
\text { totally agree } \\
\text { Total }\end{array}$ & $\begin{array}{r}1 \\
3 \\
7 \\
22 \\
33\end{array}$ & $\begin{array}{r}3.0 \\
9.1 \\
21.2 \\
66.7 \\
100.0\end{array}$ & $\begin{array}{r}3.0 \\
9.1 \\
21.2 \\
66.7 \\
100.0\end{array}$ & $\begin{array}{r}3.0 \\
12.1 \\
33.3 \\
100.0\end{array}$ \\
\hline
\end{tabular}

Learners are beneficial in meeting the requirement of the teacher and responses to learning outcomes in aspect of getting marks, improve English speaking ability when learners their perspectives are exposed based on in various levels of "quite agree, agree or totally agree" of Likert's six point scale as follow

- $\quad 69.7 \%$ of learners totally agree that they have complete their video clips punctually while more than $12 \%$ of learners agree and $15 \%$ of them quite agree. This strongly demonstrates that learner adhere to the instruction and complete learning roles (working in group to record video clips to enhance their English speaking).

- Learners admitted that their English vocabulary and pronunciation improved. More than $60 \%$ learners totally agree with that ideas, more than $20 \%$ of them agree and $18 \%$ others quite agree. This rate emphasizes that learners accomplished their English language competence is improved thanks to the activity of RVCIG.

- $51.5 \%$ learners totally agree that their fluent English speaking skill is improved thanks to many times practice speaking before recording video clips and even the action of recording video again and again when group members cannot speak or perform so well. Other learners (15\% of them agree) and more than $20 \%$ quite agree with this viewpoint. With such demonstrated percentage, learners are advantageous not only in enhancing English speaking skill but also in their soft skill of maintaining their patience, working well with partners in group.

- Learners express their roles when working in group through completing their individual work, supporting other peers and giving feedbacks or comment on their peers; performances. With this point, nearly $60 \%$ of learners totally agree, more than $30 \%$ agree and $12 \%$ quite agree. These numbers admitted that learners completely attain numerous benefit group working, language competence, confidence expression and better communicative skills. This is explained in this way if 
learners have no consciousness of group work they have not finished their individual group. Without practice their English language speaking skill learners cannot complete their personal work in a group. Without confidence, learners cannot perform their individual work and cannot help or give feedbacks to others. All these activities help learners have better communicative skill because without communication, learners have no ways to contact with friends discuss or contribute to video clip content and complete their goals. Eventually, learners improve their English language and speaking when they are confidently communicate with their partners to complete the demand of recording English video clips in group when learning English speaking skill. This explanation for advantages that learners obtained is also confirmed when $21 \%$ participants express their agreement, only $9.1 \%$ quite agree while $66.6 \%$ participants totally agree with the point that learners get more benefits in English language competence, confidence in English speaking skill, and better communication (Qarabash et al., 2019) with peers when recording video clips in group as Qarabash (2019) and his colleagues 2019 have ever said.

\section{Response for research question 3 - What challenges do the learners have to face with when conducting the activity of recording video clips in group?}

Hypothesis 3-Learners are unavoidable to cope with challenges of time consuming, technological problems and disagreement among learners when the activity of recording video clips in group conducted.

Two opposite sides of something is always parallel existed. Recording video clips in group, in fact, is unavoidable to encounter unexpected challenges such as technological problems, IT techniques, unsuccessful performance and collaboration of learners, learning motivations, and so on. Thus, to understand more learners' condition and possible troubles learners have, the interviewing question is raised to ten interviewees who have completed recording 3 video clips in group. The interviewing question 4 is "What do you need to prepare if you want to produce a quality video clip for your English speaking improvement purpose?

Ten of interviewees responded that learners need to equip themselves all necessities (such as comfortable space, available time, financial budget); learning materials (to search for topic and create a good and interesting video content); stable spirit (strong determination, dedication, patience enough in three stages of Pre, while and Post - recording a video clip); time consuming (take much time to prepare and practice before recording, and spending time for adjusting while recording and even editing or exporting video file after recording); various technological problems or techniques; clear mind of learning motivations (scores attained, meeting learning outcomes, learning objectives, language improvement, sharing learning source, English speaking enhancement, learning cooperation and collaboration).

Despite numerous challenges happened during the process of recording video clips in group but three greater problems should be con concerned as time consuming, technological problems and disagreement among group members (Shrosbree, 2008) These viewpoints are illustrated in figure 5. Nearly or more than $90 \%$ learners totally agree and agree with the ideas of time and place, technological troubles and learners disagrrement are the most challenges that they have to be suffered when conducting video clips recorded in group. This leads to the amount of time invested in this RVCIG activity or the duration of the each recoded video clip is different. More than $60 \%$ of learners spend 2 to 3 hours to complete recording a video clip and more than $40 \%$ learners record the video clips with the duration of 10 to 15 minutes and others have different time with various performances depends on their learing goals and motivation.

\begin{tabular}{|c|c|c|c|c|c|c|c|c|c|c|c|}
\hline \multicolumn{6}{|c|}{$\begin{array}{l}\text { CHALLENGES IN FINDING APPROPRIATE TIME AND PLACE TO CONDUCT } \\
\text { RECORDING VIDEO CLIPS }\end{array}$} & \multicolumn{6}{|c|}{$\begin{array}{l}\text { CHALLENGES IN TECHNOLOGICAL PROBLEMS (RECORDING, EDITING, } \\
\text { EXPORTING VIDEO FILE..., }\end{array}$} \\
\hline & & Frequency & Percent & Valid Percent & $\begin{array}{c}\text { Cumulative } \\
\text { Percent }\end{array}$ & & & Frequency & Percent & Valid Percent & $\begin{array}{l}\text { Cumulative } \\
\text { Percent }\end{array}$ \\
\hline \multirow[t]{4}{*}{ Valid } & quite agree & 4 & 12.1 & 12.1 & 12.1 & Valid & quite agree & 3 & 9.1 & 9.1 & 9.1 \\
\hline & agree & 7 & 21.2 & 21.2 & 33.3 & & agree & 5 & 15.2 & 15.2 & 24.2 \\
\hline & totally agree & 22 & 66.7 & 66.7 & 100.0 & & totally agree & 25 & 75.8 & 75.8 & 100.0 \\
\hline & Total & 33 & 100.0 & 100.0 & & & Total & 33 & 100.0 & 100.0 & \\
\hline
\end{tabular}




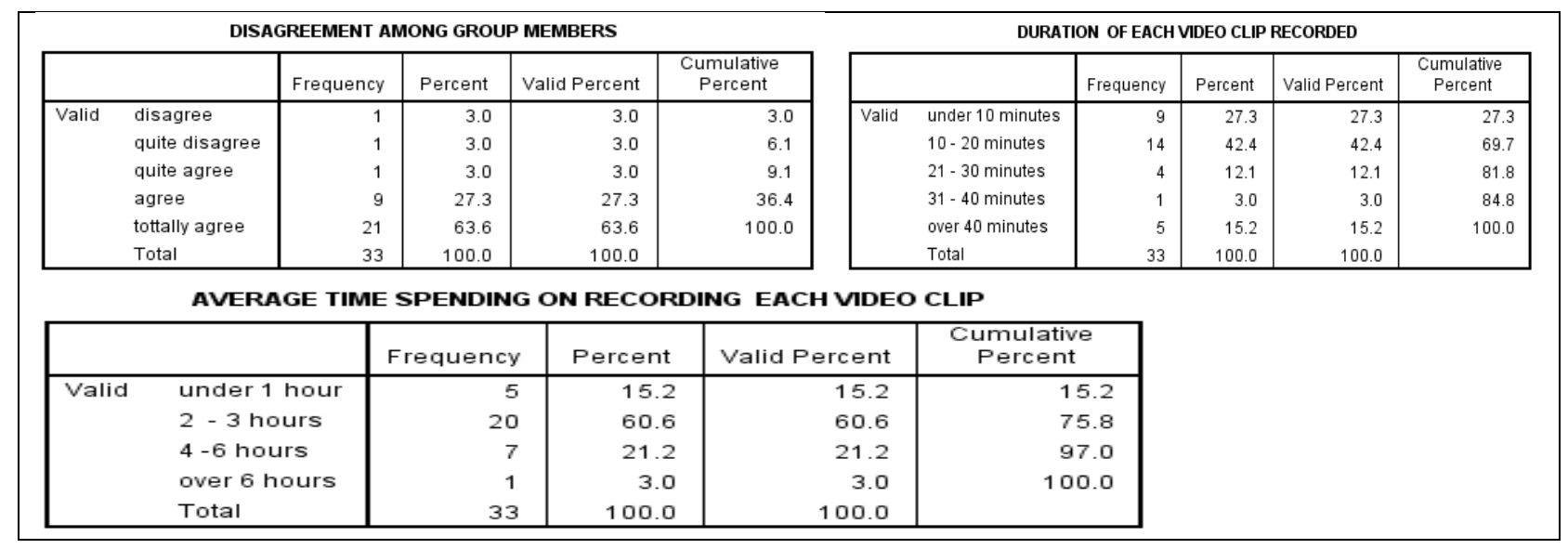

5. Response for research question 4 - How do the learners feel when recording a video clips in group? Why do learners expect to record more video clips in group when learning English speaking skill?

Hypothesis 4 - Whatever advantages and disadvantages experienced, learners are interested in recording video clips in group for reasons of mutual engagement, collaborative learning, and building friendship.

This research question is aimed to explore if learners enjoy this activity or not in order to the author can continue to use this technique in teaching English speaking later on. Thus, an interviewing question is asked ten learners in two groups.

The interviewing question 5"If you are requested to record more video clips in the next step of learning English speaking skill, Are you willingness to do that? And why?"

Ten interviewees are happy answer the question without hesitation "Yes, it is very interesting and funny". They explained "because we can work together, can play and learn at the same time, we can try the new things, change learning atmosphere and develop our creation. Although we know when recording video clip, it takes us much time, and cause troubles with recording techniques and the shortage of technological advances (mobile phones, camera, and some necessary software applications and so forth)". However, between the benefits and drawbacks of this RVCIG activity, learners strongly believed that its advantages are outweigh than its disadvantages. They also added that the most importance taken into account is that they extremely love this activity because they have fortune to work and learn together to meet the requirements of the teachers and learning outcomes. They also can improve our English speaking skill when working in group, and even learning more IT skill as well. In general, this RVCIG activity helps them to have mutual engagement, mutual learning and increase the friendships (become close friends).

\section{Conclusion}

The paper mainly focuses on exploring multiple dimensions of the activity of recording video clips in groups. Through this exploration, the teachers may understand more their young generation students in aspects of whether students are under pressure of applying IT technique in their learning process or not. Whether learners are more beneficial or disadvantageous with this RVCIG. Although the results show that various advantages and disadvantages are parallel existed and learners have various interfered feelings when conducting this RVCIG technique, or even express their preference of recording video clips in group, it is advisable that teachers should consider who their learners are, how their learners' learning history and background if this RVCIG technique is used. Moreover, this study is still limited in number of participant (just 33 participants in an English speaking class). Thus, more studies related to this RVCIG should be continuously conducted.

\section{References}

[1] Alley-Young, G. (2017). Creating digital videos in an ESL learning community to develop communication skills and content area knowledge Unplugging the Classroom (pp. 13-35): Elsevier.

[2] Biegel, K. (1998). It's show time: Video production in the EFL classroom. The Language Teacher, 22(8), 1114. 
[3] Burston, J. (2005). Video dubbing projects in the foreign language curriculum. Calico Journal, 79-92.

[4] Fadde, P. J., Aud, S., \& Gilbert, S. (2009). Incorporating a video-editing activity in a reflective teaching course for preservice teachers. Action in teacher education, 31(1), 75-86.

[5] Hashimoto, K., \& Nguyen, V.-T. (2018). Professional Development of English Language Teachers in Asia: Lessons from Japan and Vietnam: Routledge.

[6] Herron, C., Morris, M., Secules, T., \& Curtis, L. (1995). A comparison study of the effects of video-based versus text-based instruction in the foreign language classroom. French Review, 775-795.

[7] Hirata, Y. (2009). Application of Video Recording in the Llanguage Classroom.

[8] Jacucci, G., Oulasvirta, A., Salovaara, A., \& Sarvas, R. (2005). Supporting the shared experience of spectators through mobile group media. Paper presented at the Proceedings of the 2005 international ACM SIGGROUP conference on Supporting group work.

[9] Lian, A.-P., Thornquist, L. N., \& Thornquist, L. E. (1987). Computer-Based Technology in Language Learning. IALLT Journal of Language Learning Technologies, 20(2), 24-31.

[10] Lian, A. (1991). What is CALL software. On-CALL, 5(4), 2-8.

[11] Lian, A., \& Pineda, M. V. (2014). Rhizomatic learning:“As... when... and if...” A strategy for the ASEAN community in the 21st century. Beyond Words, 2(1), 1-28.

[12] Michaelsen, L. K., Fink, L. D., \& Knight, A. (1997). Designing effective group activities: Lessons for classroom teaching and faculty development. To improve the academy, 16(1), 373-397.

[13] Odhabi, H., \& Nicks-McCaleb, L. (2011). Video recording lectures: Student and professor perspectives. British Journal of Educational Technology, 42(2), 327-336.

[14] Oradee, T. (2012). Developing speaking skills using three communicative activities (discussion, problemsolving, and role-playing). International Journal of Social Science and Humanity, 2(6), 533.

[15] Qarabash, H., Heslop, P., Kharrufa, A., Balaam, M., \& Devlin, M. (2019). Group tagging: Using video tagging to facilitate reflection on small group activities. British Journal of Educational Technology, 50(4), 1913-1928.

[16] Roschelle, J., \& Teasley, S. D. (1995). The construction of shared knowledge in collaborative problem solving. Paper presented at the Computer supported collaborative learning.

[17] Shinohara, Y. (1997). The group video presentation project. LANGUAGE TEACHER-KYOTO-JALT-, 21, 3939.

[18] Shrosbree, M. (2008). Digital video in the language classroom. The JALT Call Journal, 4(1), 75-84.

[19] Stempleski, S. (1987). Short Takes: Using Authentic Video in the English Class.

[20] Suwartono, S. (2014). Enhancing the pronunciation of English suprasegmental features through reflective learning method. TEFLIN Journal, 25(1), 80-93.

[21] Swaffar, J., \& Vlatten, A. (1997). A sequential model for video viewing in the foreign language curriculum. The Modern Language Journal, 81(2), 175-188.

[22] Teng, F. (2019). The effects of video caption types and advance organizers on incidental L2 collocation learning. COMPUTERS \& EDUCATION, 142.

[23] Weyers, J. R. (1999). The effect of authentic video on communicative competence. The Modern Language Journal, 83(3), 339-349.

Links https://dictionary.cambridge.org/dictionary/english/multiple https://futurism.com/understanding-10-dimensional-universe 